Tropical Journal of Pharmaceutical Research December 2013; 12 (6): 959-965

ISSN: 1596-5996 (print); 1596-9827 (electronic) (C) Pharmacotherapy Group, Faculty of Pharmacy, University of Benin, Benin City, 300001 Nigeria. All rights reserved.

Available online at http://www.tjpr.org Original Research Article http://dx.doi.org/10.4314/tjpr.v12i6.14

\title{
Ginger Essential Oil Ameliorates Cisplatin-Induced Nephrotoxicity in Mice
}

\section{Marcio J Damião ${ }^{1}$, Gisele Giannocco ${ }^{2}$, Renata Grespan ${ }^{1}$, Expedito L Silva ${ }^{3}$, Janaina S Duarte ${ }^{2}$, Rui MB Maciel ${ }^{2}$, Alciléia N Yamada1, Ciomar A Bersani- Amado $^{1}$ and Roberto KN Cuman ${ }^{1 *}$}

${ }^{1}$ Department of Pharmacology and Therapeutics, State University of Maringá, Maringá, Paraná, ${ }^{2}$ Department of Endocrinology, Federal University of São Paulo, CEP 04039002, São Paulo, ${ }^{3}$ Department of Chemistry, State University of Maringá, Maringá, Paraná, Brazil

*For correspondence: Email: rkncuman@uem.br; Tel: 55-44-30114867; Fax: 55-44-30114999.

\begin{abstract}
Purpose: To investigate the effect of ginger essential oil (GEO) in an experimental model of cisplatininduced nephrotoxicity.

Methods: Male mice were divided into treatment six groups ( $n=7)$, namely: Groups I (saline), II and III (cisplatin, $10 \mathrm{mg} / \mathrm{kg}$, i.p.) euthanized in $3^{\text {th }}$ and $6^{\text {th }}$ days, respectively, and IV, V and IV (GEO, 100, 200 and $400 \mathrm{mg} / \mathrm{kg} /$ day, respectively, by gavage 3, 4, 5 and 6 days after cisplatin injection). Creatinine levels and protein/creatinine ratio were determined in plasma and urine, respectively. Bone morphogenic protein (BMP-7) and tumor necrosis factor (TNF- $\alpha$ ) levels of kidney tissues were determined while $m R N A$ expression levels were obtained using real-time polymerase chain reaction. Results: GEO treatment reduced significantly creatinine levels to $0.53 \pm 0.02 ; \quad 0.48 \pm 0.008$ and $0.46 \pm 0.02$ at 100, 200 and $400 \mathrm{mg} / \mathrm{kg}$, respectively, compared with control $(0.70 \pm 0.01)$ [p<0.05] but increased protein : creatinine ratio to $0.21 \pm 0.01,0.22 \pm 0.01,0.24 \pm 0.02$ compared with control $(0.06 \pm$ 0.008 ) $[p<0.05]$. Pro-inflammatory TNF- $\alpha$ mRNA expression was decreased to $1.46 \pm 0.21,1.39 \pm 0.19$ and $1.36 \pm 0.09$, at GEO doses of 100,200 and $400 \mathrm{mg} / \mathrm{kg}$, respectively, while anti-fibrotic BMP-7 mRNA expression increased to $2.05 \pm 0.26$ and $2.44 \pm 0.42$ at doses of 200 and $400 \mathrm{mg} / \mathrm{kg}$, respectively, compared with control $(0.59 \pm 0.39, p<0.05)$.

Conclusion: GEO treatment attenuates cisplatin-induced nephrotoxicity, in part, by modulating some inflammatory cytokines.
\end{abstract}

Keywords: Zingiber officinale, Ginger, Roscoe, Essential oil, Nephrotoxicity, Cisplatin.

Tropical Journal of Pharmaceutical Research is indexed by Science Citation Index (SciSearch), Scopus, International Pharmaceutical Abstract, Chemical Abstracts, Embase, Index Copernicus, EBSCO, African Index Medicus, JournalSeek, Journal Citation Reports/Science Edition, Directory of Open Access Journals (DOAJ), African Journal Online, Bioline International, Open-J-Gate and Pharmacy Abstracts

\section{INTRODUCTION}

Acute kidney injury is a common disorder that develops in approximately $25 \%$ of patients after high-dose cisplatin cancer chemotherapy [1]. Among multiple mechanisms of action, the induction of inflammatory cytokines, oxidative stress, increased creatinine levels, and apoptosis of renal cells are involved in cisplatin-induced nephrotoxicity [2]. Cisplatin initiates the inflammatory process via tumor necrosis factor- $\alpha$ $(\mathrm{TNF}-\alpha)$ production by resident and infiltrating immune cells [3]. Several natural products have been used to protect against toxicity induced by drugs and carcinogenic xenobiotics [4]. Different pharmacological activities have also been 
reported for Zingiber officinale Roscoe, Salvia officinalis $L$. and Syzygium aromaticum $L$. essential oils, including antioxidant, antiinflammatory, antiviral, antibacterial and anticancer effects [5].

Furthermore, ginger extract suppresses the induction of pro-inflammatory cytokines and chemokine expression produced by synoviocytes, chondrocytes, and leukocytes in humans [6]. A previous study suggested that ginger effectively restores cisplatin-induced delays in gastric emptying in rats [7]. We recently demonstrated that ginger essential oil (GEO) presents anti-inflammatory and immunomodulatory activities in animal models [8]. Indeed, other studies have demonstrated the reno-protective effects of ginger extract in different experimental models of renal failure $[9,10]$.

However, no studies about the reno-protective effects of GEO have been investigated. Therefore, the aim of the present study was to evaluate the effect of GEO in an experimental model of cisplatin-induced nephrotoxicity.

\section{EXPERIMENTAL}

\section{Plant material and essential oil extraction}

Fresh rhizomes of Zingiber officinale Roscoe were collected in June 2011 from the Prof $^{a}$ Irenice Silva Medicinal Plant Garden on the campus of the State University of Maringá, Paraná, Brazil, identified, and authenticated by taxonomist Maria Aparecida Sert. Voucher specimen was deposited in the Herbarium of the Department of Botany, State University of Maringá (no. 11612). GEO was extracted by conventional steam distillation using a Clevenger- type apparatus for $3 \mathrm{~h}$. The essential oil was stored at $4{ }^{\circ} \mathrm{C}$ in dark vials, pending further tests.

\section{Gas chromatography-mass spectrometry}

Gas chromatography (GC) was performed using a Thermo Electron Corporation Focus GC model under the following conditions: DB-5 capillary column $(30 \mathrm{~m} \times 0.32 \mathrm{~mm}$. $0.50 \mathrm{~mm})$, column temperature $\left(60{ }^{\circ} \mathrm{C}\right.$ for $1 \mathrm{~min}$ to $180{ }^{\circ} \mathrm{C}$ at 3 $\left.{ }^{\circ} \mathrm{C} / \mathrm{min}\right)$, injector temperature $\left(220{ }^{\circ} \mathrm{C}\right)$, detector temperature $\left(220{ }^{\circ} \mathrm{C}\right)$, split ratio $(1: 10)$, carrier gas $(\mathrm{He})$, flow rate $(1.0 \mu \mathrm{l} / \mathrm{min})$. The volume injected was $1 \mu$ liluted in acetone (1:10). GC/MS analyses were performed using a Quadrupole mass spectrometer (Thermo Electron, DSQ II model) that operated at $70 \mathrm{~V}$. The identification of the individual components was based on a comparison of their GC retention indices obtained with reference to n-alkane series $\mathrm{C}_{8} \mathrm{H}_{18}-\mathrm{C}_{20} \mathrm{H}_{42}$ (Sigma, St. Louis, MO, USA) on a DB-5 column and comparison with the mass spectra of an authentic standard purchased from Sigma-Aldrich [11]. The retention indices (RI) were obtained with reference to n-alkane $\mathrm{C}_{7} \mathrm{H}_{16}-\mathrm{C}_{44} \mathrm{H}_{90}$ series (Supelco-Bellefonte USA, UK).

\section{Nuclear magnetic resonance}

Nuclear magnetic resonance (NMR) was used to prove the chemical structure of the essential oil constituents identified by CG-MS. ${ }^{1} \mathrm{H}$ (300.06 $\mathrm{MHz})$ and ${ }^{13} \mathrm{C}$ NMR $(75.45 \mathrm{MHz})$ spectra were recorded in a deuterated chloroform $\left(\mathrm{CDCl}_{3}\right)$ solution using a Mercury-300BB spectrometer, with $\delta(\mathrm{ppm})$ and spectra referenced to $\mathrm{CDCl} 3(\delta$ 7.27 for ${ }^{1} \mathrm{H}$ and $\delta 77.00$ for ${ }^{13} \mathrm{C}$ ) as the internal standard.

\section{Experimental animals}

Male Swiss albino mice, 5 to 6 weeks of age and $20-25 \mathrm{~g}$, were provided by the Central Animal House of the State University of Maringá. The animals were housed at $22 \pm 2{ }^{\circ} \mathrm{C}$ under a $12 \mathrm{~h} / 12 \mathrm{~h}$ light/dark cycle. All of the animals were housed in individual standard cages with free access to water and feed. The experimental protocols were approved by the Ethical Committee in Animal Experimentation of the State University of Maringá (ref no. 024/2010CEEA/UEM).

\section{Drug}

Cisplatin was obtained from Darrow Laboratories (Rio de Janeiro, Brazil).

\section{Experimental design}

The animals were divided into six groups. Normal group I was injected (i.p.) with saline. Cisplatin (CP) control groups (CTL) II and III were injected with $\mathrm{CP}(10 \mathrm{mg} / \mathrm{kg}$, i.p.) and in the third and sixth days, respectively, the groups were anesthetized under ketamine (100 mg/kg, i.p.) and xylazine (10 $\mathrm{mg} / \mathrm{kg}$, i.p.) to evaluation of some parameters below described. Groups IV, V, VI were treated with 100, 200 and $400 \mathrm{mg} / \mathrm{kg}$ of GEO, respectively, by gavage $(3,4,5$, and 6 days after $\mathrm{CP}$ injection) and thereafter anesthetized as CTL groups. Each of the groups had seven animals, with the exception of Group III, which had 18 animals because some of them died between third and sixth days after cisplatin injection. 


\section{Analysis of kidney function}

Blood was collected directly from the abdominal aorta and then centrifuged. The serum was separated for the determination of serum creatinine levels. Urine was collected from the bladder to measure urinary protein and creatinine levels using a commercial kit (Gold Analisa ${ }^{\circledR}$ ) for calculating the urinary protein : creatinine ratio.

\section{Quantification of mRNA}

Kidney samples were quickly stored in liquid nitrogen. Total RNA was isolated from the kidney using TRIZOL reagent (Invitrogen, Carlsbad, CA, USA), and RNA levels were determined by ultraviolet light absorbance at $260 \mathrm{~nm}$ using a Nanodrop 2000C spectrophotometer (Thermo Scientific). First-strand cDNAs were synthesized using MML-V reverse transcriptase (Promega, Madison, WI, USA). Reverse transcription polymerase chain reaction (RT-PCR) was performed using the SYBR Green real-time PCR assay (Applied Biosystems, USA). The following primer sequences were used: TNF- $\alpha$ (sense: 5'ATG AGC ACA GAA AGC ATG ATCAGC-3'; antisense: 5'-ACG AGG AAT GAG AAG AGG GTC AGA-5'), BMP-7 (sense: 5'-AGA ATT CTT CCA CCC TGC ATA CC-3'; antisense: 5'-TCC
TTA TAG ATC CTG AAT TGG GCT-3'). mRNA expression was normalized to hypoxanthine guanine phosphoribosyl transferase (HPRT; sense: 5'-CTC ATG CAC TGA TTA TGG AGA GGA C-3'; antisense: 5'-GCA GGT CAG CAA AGA ACT TAT AGC C-3'), which was used as the housekeeping gene. All data were expressed relative to the expression of the matched controls.

\section{Statistical analysis}

The data are expressed as mean \pm SEM for each group and were statistically analyzed using oneway analysis of variance (ANOVA) followed by Tukey's test Graph Pad Prism software (version $5)$. Differences were considered significant at $p<$ 0.05 .

\section{RESULTS}

The results of the GEO chemical analysis, retention indices, and area percentages are shown in Fig. 1 and Table 1. The chromatographic analysis identified 34 components, representing $99.3 \%$ of the total GEO.

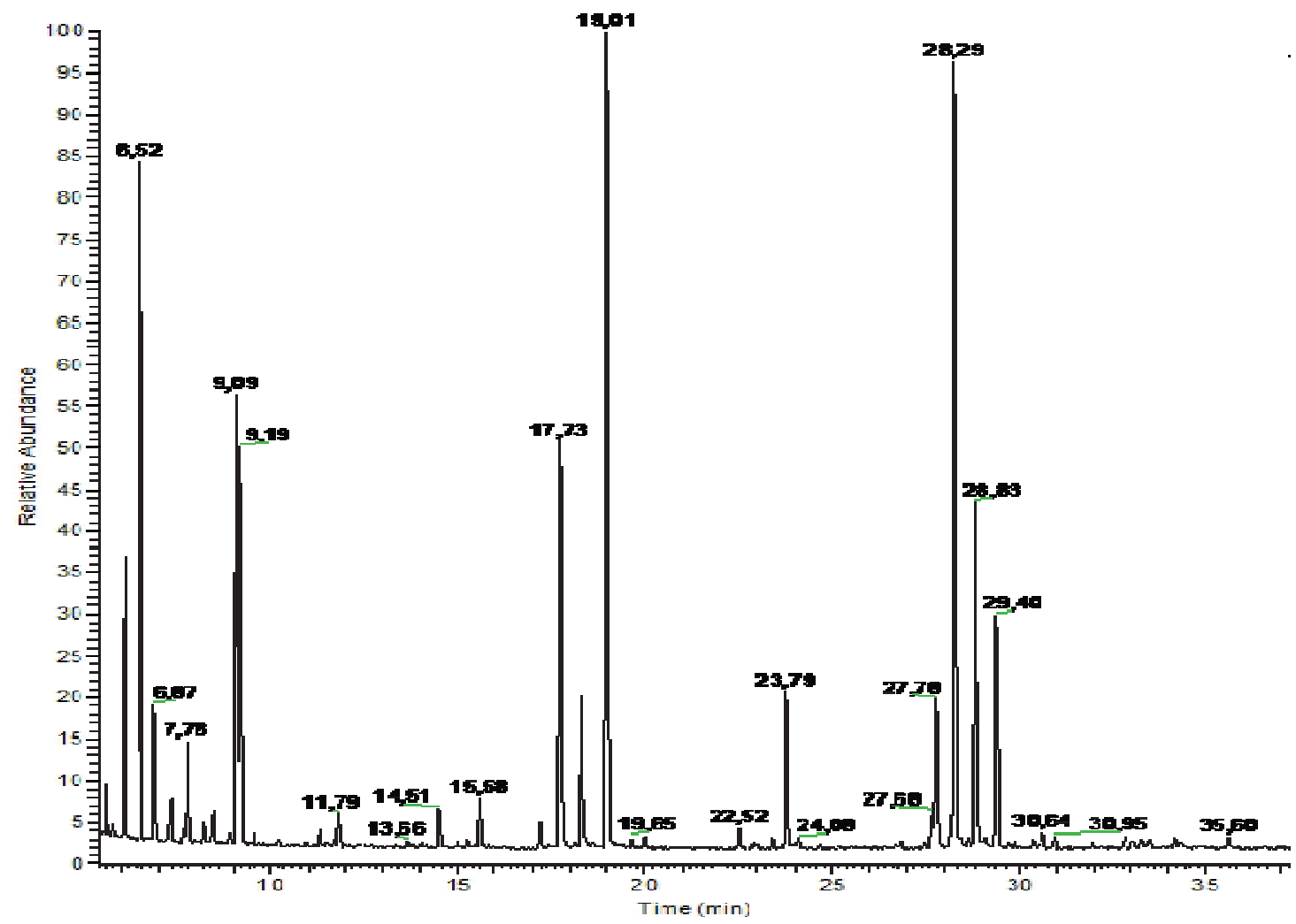

Figure 1: GC chromatogram of rhizomes of Zingiberofficinale Roscoe essential oil 
As shown in Table 1, GEO contained a high amount of $\alpha$-zingiberene (16.2\%), followed by geranial (15.3\%), camphene (9.37\%), neral (7.7 $\%), \quad \beta$-phellandrene (7.6 \%), and (E,E)- $\alpha$ farnesene $(7.4 \%)$, representing a total of $63.5 \%$ and indicating a preponderance of terpene (monoterpene) compounds. The presence of numerous other constituents at concentrations ranging from 0.2 to $6.5 \%$ of the essential oil was also observed.

\section{Seric creatinine}

Seric creatinine level was significantly elevated on the $3 \mathrm{rd}(0.65 \pm 0.03 \mathrm{mg} / \mathrm{dl})$ and 6 th day $(0.70$ $\pm 0.01 \mathrm{mg} / \mathrm{dl})$ after cisplatin injection compared with $0.41 \pm 0.008 \mathrm{mg} / \mathrm{dl}$ for normal control.GEO administration after cisplatin injection decreased significantly creatinine level to $0.53 \pm 0.02,0.48 \pm$ 0.02 and $0.46 \pm 0.02 \mathrm{mg} / \mathrm{dl}$ at 100,200 and 400 $\mathrm{mg} / \mathrm{kg}$, respectively, on the $6^{\text {th }}$ day, compared with cisplatin control $[p<0.05]$., as shown in Fig 2a.

\section{Urinary protein/creatinine ratio}

Urinary protein: creatinine ratio on the $3 \mathrm{rd}(0.11$ $\pm 0.01 \mathrm{mg} / \mathrm{dl})$ and 6 th day $(0.06 \pm 0.01 \mathrm{mg} / \mathrm{dl})$ after cisplatin injection, was lower than that of normal group $(0.41 \pm 0.02 \mathrm{mg} / \mathrm{dl})$, reflecting the

Table 1: Chemical composition of Zingiber officinale Roscoe essential oil

\begin{tabular}{|c|c|c|c|}
\hline $\mathbf{R I}^{\mathrm{a}}$ & Compound & Content (\%) & Technique used \\
\hline 953 & a-pinene & 3,6 & GC/MS, NMR \\
\hline 967 & Camphene & 9,3 & GC/MS, NMR \\
\hline 991 & Sabinene & 0,2 & GC/MS, NMR \\
\hline 994 & a-pinene & 0,8 & GC/MS, NMR \\
\hline 1005 & Mycene & 1,7 & GC/MS, NMR \\
\hline 1017 & a-phellandrene & 0,4 & GC/MS, NMR \\
\hline 1032 & p-cymene & 0,2 & GC/MS, NMR \\
\hline 1036 & $\beta$-phellandrene & 7,6 & GC/MS, NMR \\
\hline 1039 & 1,8-cineole & 6,5 & GC/MS, NMR \\
\hline 1062 & a-terpinene & 0,1 & GC/MS, NMR \\
\hline 1089 & Terpinolene & 0,4 & GC/MS, NMR \\
\hline 1100 & Linalool & 0,8 & GC/MS, NMR \\
\hline 1165 & Borneol & 0,9 & GC/MS, NMR \\
\hline 1190 & a-terpineol & 1,0 & GC/MS, NMR \\
\hline 1228 & Citronellol & 0,5 & GC/MS, NMR \\
\hline 1240 & Neral & 7,7 & GC/MS, NMR \\
\hline 1254 & Geraniol & 3,4 & GC/MS, NMR \\
\hline 1270 & Geranial & 15,3 & GC/MS, NMR \\
\hline 1285 & bornyl acetate & 0,3 & GC/MS \\
\hline 1353 & citronellyl acetate & 0,6 & GC/MS \\
\hline 1363 & no identified & 0,3 & - \\
\hline 1374 & a-copaene & 0,3 & GC/MS, NMR \\
\hline 1383 & geranyl acetate & 3,0 & GC/MS, NMR \\
\hline 1390 & $\beta$-elemene & 0,3 & GC/MS \\
\hline 1479 & germacrene D & 0,7 & GC/MS, NMR \\
\hline 1481 & ar-curcumene & 3,2 & GC/MS, NMR \\
\hline 1491 & $\beta$-selinene & 0,8 & GC/MS \\
\hline 1494 & a-zingiberene & 16,2 & GC/MS, NMR \\
\hline 1508 & $(E, E)-\alpha$-farnesene & 7,4 & GC/MS, NMR \\
\hline 1522 & sesquiphellandrene & 4,4 & GC/MS, NMR \\
\hline 1555 & Z-Nerolidol & 0,5 & GC/MS \\
\hline 1563 & E-Nerolidol & 0,3 & GC/MS \\
\hline 1612 & $\beta$-bisabolol & 0,3 & GC/MS \\
\hline 1687 & $(E, Z)$-a-farnesol & 0,3 & GC/MS \\
\hline Total identified & \multicolumn{3}{|c|}{$99.3 \%$} \\
\hline
\end{tabular}


${ }^{a} R I$ : Retention index relative to a homologous series of $n$-alkanes on the DB- 5 capillary colunn. MS, mass spectometry; NMR, nuclear magnetic resonance.
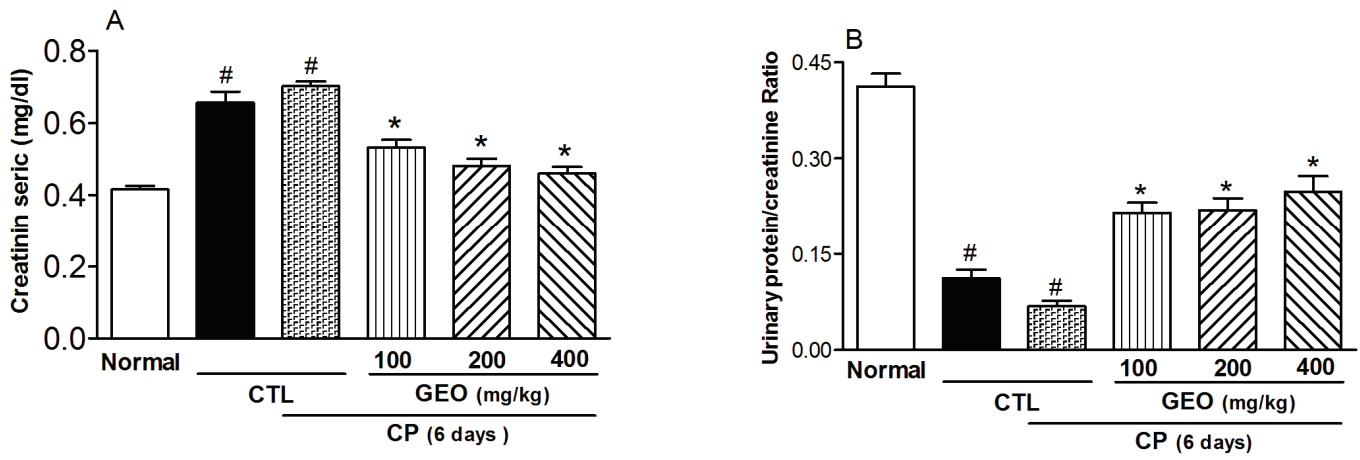

Fig 2: Effect of ginger essential oil (GEO) on cisplatin-induced renal dysfunction
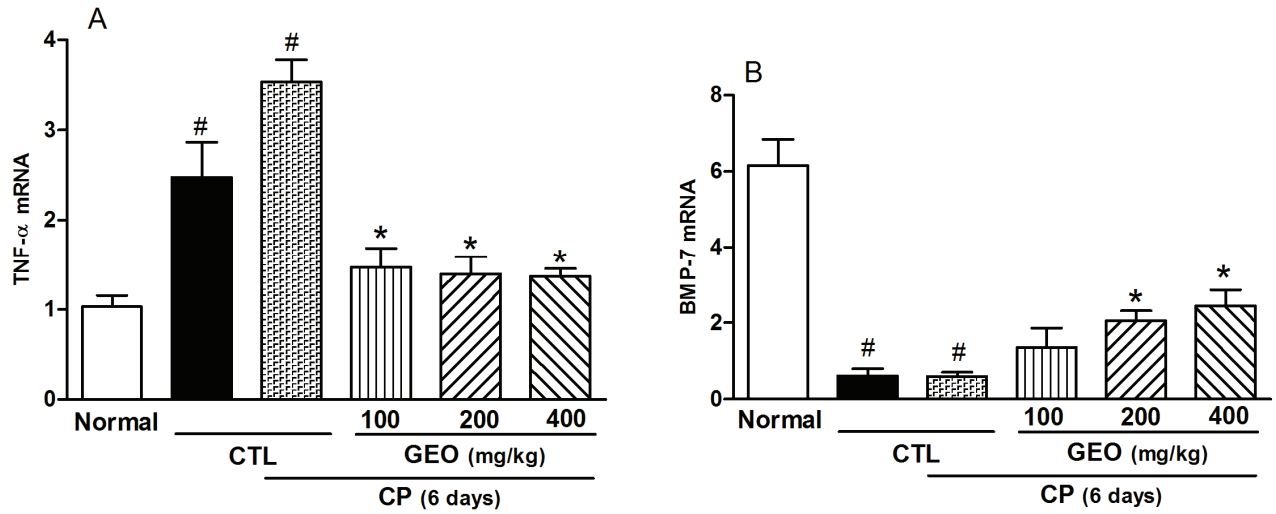

Fig 3: Changes in the expression of TNF- $\alpha$ and BMP-7 after administration of ginger essential oil (GEO) in a cisplatin-induced nephrotoxicity model in mice; ${ }^{\sharp} p<0.05$, compared with normal group; ${ }^{*} p<0.05$, compared with renal injury induced by CP (6 days).

impairment of renal function. The groups that received GEO at doses of 100,200 and 400 $\mathrm{mg} / \mathrm{kg}$ after cisplatin injection increased the ratio to $0.21 \pm 0.01,0.22 \pm 0.01$, and $0.24 \pm 0.02$ $\mathrm{mg} / \mathrm{dl}$, respectively (Fig $2 \mathrm{~b}, p<0.05)$.

\section{TNF- $\alpha$ mRNA expression levels}

The TNF- $\alpha$ gene mRNA expression levels were markedly upregulated on 3rd day $(2.47 \pm 0.39)$ and 6th $(3.53 \pm 0.24)$ day after cisplatin injection compared with normal group (1.02 \pm 0.12$)$ $[p<0.05]$. The groups that received GEO after cisplatin injection inhibited significantly TNF- $\alpha$ mRNA expression level to $1.46 \pm 0.21,1.39 \pm$ 0.19 and $1.36 \pm 0.09$ at doses of 100,200 and $400 \mathrm{mg} / \mathrm{kg}$, respectively, on the 6 th day, compared with control (Fig 3a).

\section{BMP-7 mRNA expression levels}

BMP-7 mRNA expression levels on the 3rd (0.61 $\pm 0.18)$ and 6 th days $(0.59 \pm 0.11)$ after cisplatin injection were significantly lower than that of normal control $(6.16 \pm 0.68)$. The groups that received GEO at doses of 200 and $400 \mathrm{mg} / \mathrm{kg}$ following cisplatin injection significantly increased BMP-7 mRNA expression level to $2.05 \pm 0.26$ and $2.44 \pm 0.42$, respectively, compared with control $(p<0.05)$. However, there was no significant increase in BMP-7 mRNA expression level in the group that received GEO at a dose of $100 \mathrm{mg} / \mathrm{kg}(1.35 \pm 0.50)$, as Fig $3 \mathrm{~b}$ shows.

\section{DISCUSSION}

The present study was aimed at investigating the nephro-protective potentials of ginger essential oil (GEO) against cisplatin-induced toxicity. Renal damage caused by cisplatin depends on the dose and duration of treatment. This study was carried out at a high dose of cisplatin (10 $\mathrm{mg} / \mathrm{kg} /$ body weight, i.p) to produce a nephrotoxic effect that corresponds to the dose of cisplatin currently being used in clinical practice. This experimental model is important because accidental cisplatin overdose can be toxic in humans and lead to renal failure [12]. 
Besides, GEO presents many biological activities, such as antiinflammatory, antiemetic, and antineoplastic effects, some studies have demonstrated the renoprotective effect $[7,13]$. However, this effect has been showed with ginger extracts in nephropathy induced by carbon tetrachloride $\left(\mathrm{CCl}_{4}\right)$ in rats [7] and against cisplatin-induced nephrotoxicity in mice [13]. In this study, seric creatinine levels were significantly elevated in the control group 3 days and 6 days after cisplatin injection compared with normal control. While GEO administration after cisplatin injection decreased creatinine levels at all test doses 6 days after cisplatin injection.

Hemmelgarn et al [14] showed that chronic kidney disease has a high prevalence of albuminuria and glomerular injury. In this case, albuminuria detection allows therapeutic intervention and the prevention of renal failure. Moreover, urinary protein : creatinine ratio has been shown to be an accurate and reliable method for estimating protein in the urine in many cases, such as in diabetic nephropathy and kidney-transplanted patients [15, 16]. Indeed, acute kidney injury induced by cisplatin administration in rats causes a significative reduction in the glomerular filtration rate and an increase in serum levels of urea and creatinine $[17,18]$. In the present study, administration of cisplatin lowered urinary protein:creatinine ratio, reflecting impairment in renal function but the ratio rose following GEO administration. These results indicate the amelioration of kidney function indicators, such as urinary protein and creatinine levels, after administration of GEO in cisplatin-treated mice, as also observed for other natural products $[19,20]$.

Increasing evidence suggest the involvement of inflammatory processes in renal injury, including expression of genes that encode proinflammatory cytokines, such as TNF- $\alpha$, interleukin 6 (IL-6), IL-1 $\beta$, and transforming growth factor $\beta$, which potentiate inflammation [21]. Previous studies suggested that TNF- $\alpha$ inhibition ameliorates cisplatin-induced renal disfunction [22]. Some natural products have been reported to suppress inflammatory processes by inhibiting the production of TNF- $\alpha$ and IL-1 $\beta$. In this regard, ginger extract has been demonstrated to inhibit proinflammatory cytokine (TNF- $\alpha$, IL-1 $\beta$ ) and cyclooxygenase- 2 enzyme expression in TNF- $\alpha-$, IL-1 $\beta$, or lipopolysaccharide-induced THP-1 cells [23]. Our data show that TNF- $\alpha$ gene was markedly upregulated after cisplatin injection and that GEO administration inhibited TNF- $\alpha$ mRNA expression level at all the tested doses, suggesting that the reno-protective effect of GEO may be attributable to inhibition of pro-inflammatory cytokines, such as TNF- $\alpha$ and IL- $1 \beta$.

Bone morphogenetic protein-7 (BMP-7) has been shown to participate in organ development, regeneration, and wound healing and has diverse biological functions. Over-expression of renal BMP-7 is capable of inhibiting TGF$\beta /$ Smad3 signaling and protecting the kidney from TGF- $\alpha$-mediated renal injury [24]. BMP-7 can suppress TNF- $\alpha$-induced inflammatory responses during nephropathy by inhibiting the activity of nuclear factor- $\mathrm{KB}$ and increasing the activity of peroxisomal proliferator-activated receptor- $\gamma$ in an immunoglobulin A-induced nephropathy model [20]. In our study, we observed that GEO treatment increases BMP-7 mRNA expression. BMP-7 has been reported to protect against ischemic injury by acting on proximal tubular epithelial cells to reduce TNF- $\alpha$, IL-6, and IL-1 $\beta$ expression [25].

\section{CONCLUSION}

GEO treatment has beneficial effects in an experimental mice model of cisplatin-induced nephrotoxicity, as reflected by decreased creatinine levels and increase in the protein : creatinine ratio. GEO also inhibits the expression of pro-inflammatory TNF- $\alpha$ cytokine levels and protects against ischemic injury by increasing BMP-7 expression. Thus, GEO treatment may poessess potential benefits to renal patients. However, further investigations are essential to elucidate the mechanism by which GEO treatment ameliorates the nephrotoxicity.

\section{ACKNOWLEDGMENT}

This study was supported by grants from the Coordenadoria de Aperfeiçoamento de Pessoal de Nível Superior, Capes, and Conselho Nacional de Desenvolvimento Científico e Tecnológico, Brazil. We thank Mr. Jailson Araujo Dantas and Mrs. Celia Regina Miranda for technical assistance.

\section{REFERENCES}

1. Pabla N, Dong Z. Cisplatin nephrotoxicity: Mechanisms and renoprotective strategies. Kidney Int 2008, 73: 994-1007.

2. Yao X, Panichpisal K, Kurtzman N, Nugent K. Cisplatin nephrotoxicity. Am J Med Sci 2007; 334: 115124.

3. Zhang B, Ramesh G, Norbury CC, Reeves WB. Cisplatininduced nephrotoxicity is mediated by tumor necrosis factor-alpha produced by renal parenchymal cells. Kidney Int 2007; 72: 37-44.

4. Vutyavanish T, Kraisarin T, Ruangsri R. Ginger for nausea and vomiting in pregnancy: randomized, double- 
masked, placebo-controlled trial. Obstet Gyneco 2001; 97: 577-582.

5. Edris AE. Pharmaceutical and therapeutic potential of essential oils and their individual volatile constituents. Phytother Res 2007; 21: 308-323.

6. Phan PV, Sohrabi A, Polotsky A, Hungerford DS, Lindmark L, Frondoza CG. Ginger extract components suppress induction of chemokine expression in human synoviocytes. J Altern Complement Med 2005; 11: 149-154.

7. Sharma. SS, Gupta YK. Reversal of cisplatin-induced delay in gastric emptying in rats by ginger (Zingiber officinale). J Ethnopharcol 1998; 62: 4955.

8. Mello GAN, Grespan R, Fonseca JP, Farinha TO, Silva EL, Romero AL, Bersani-Amado CA, Cuman RKN. Inhibitory effects of ginger (Zingiber officinale Roscoe) essential oil on leukocyte migration in vivo and in vitro. J Nat Med 2011; 65: 241-246.

9. Manal. A, Saana AA, EL-Rigal NS. Therapeutic Potential of Ginger against Renal Injury Induced by Carbon Tetrachloride in rats. Scientific World Journa 2012; Art ID 840421, 12 p.

10. Mahmoud MF, Diaai AA, Ahmed F. Evaluation of the efficacy of ginger, Arabic gum, and Boswellia in acute and chronic renal failure. Ren Fail 2011; 34: 73-82.

11. Adams RP, Identification of Essential Oil Components by Gas chromatography/Mass Spectroscopy, $4^{\text {th }}$ ed. Allured Publishing Corporation 2007; Caro Stream, III, USA..

12. Chu G, Mantin R, Shen Y, Baskett G, Sussman $H$. Massive cisplatin overdose by accidental substitution for carboplastin. Cancer 1993; 72: 3707-3714.

13. Ajith TA, Hema $U$, Aswathy MS. Zingiber officinale Roscoe prevents acetaminophen-induced acute hepatotoxicity by enhancing hepatic antioxidant status. Food Chem Toxicol 2007; 45: 2267-2272.

14. Hemmelgarn BR, Manns BJ, Lloyd A, James MT, Klarenbach S, Quinn RR, Wiebe N, Tonelli $M$. Relation between kidney function, proteinuria and adverse outcomes. JAMA 2010; 3; 303: 423-429.

15. Panduru NM, Forsblom C, Saraheimo M, Thorn L, Bierhaus A, Humpert PM, Groop PH, on behalf of the Finn Diane Study Group. Urinary Liver-Type Fatty Acid-Binding Protein and Progression of Diabetic Nephropathy in Type 1 Diabetes. Diabetes Care 2013; 36: 2077-2083.

16. Morales JV, Vaisbich MH, Heilberg IP, Mastroianni KG, Barros EJG. Urine random samples versus 24hour collections their role in clinical practice. $J$ Bras Nefrol 2006; 28: 33-40.

17. Rjiba-Touati K, Boussema IA, Belarbia A, Achour A, Bacha $H$. Protective effect of recombinant human erythropoietin against cisplatin-induced oxidative stress and nephrotoxicity in rat kidney. Int $J$ Toxicol 2011; 30: 510-517.

18. Atessahin A, Yilmaz S, Karahan I, Ceribasi AO, Karaoglu A. Effects of lycopene against cisplatin-induced nephrotoxicity and oxidative stress in rats. Toxicology 2005; 212: 116-123.

19. Joy J, Nair CK. Amelioration of cisplatin induced nephrotoxicity in Swiss albino mice by Rubia cordifolia extract. J Cancer Res Ther 2008; 4: 111-115.

20. Mazaheri S, Nematbakhsh M, Bahadorani M, Pezeshki Z, Talebi A, Ghannadi AR, Ashrafi F. Effects of fennel essential oil on cisplatin-induced nephrotoxicity in ovariectomized rats. Toxicol int, 2013; 20: 138-145

21. Daha MR, Van KC. Is the proximal tubular cell a proinflammatory cell. Nephrol Dial Transplant 2000; 15: 41-46.

22. Ramesh G, Reeves WB. Salicylate reduces cisplatin nephrotoxicity by inhibition of tumor necrosis factor-alfha. Kidney Int 2004; 65: 490-499.

23. Grzanna R, Phan P, Polotsky A, Lindmark L, Frondoza CG. Ginger extract inhibits beta-amyloid peptideinduced cytokine and chemokine expression in cultured THP-1 monocytes. J Altern Complement Med 2004; 6: 1009-1013.

24. Meng XM, Chung AC, Lan HY. Role of the TGF- $\beta / B M P$ 7/Smad pathways in renal diseases. Clin Sci Lond 2013. 124: 243-254.

25. Gould SE, Day M, Jones SS, Dorai H. BMP-7 regulates chemokine, cytokine and hemodynamic gene expression in proximal tubule cells. Kidney Int 2002; 61: 51-60. 